\title{
EROSIVIDADE DA CHUVA PARA MUNICÍPIO DE SÃO MATEUS-ES (2014 A 2016)
}

\section{Dione Pereira Cardoso ${ }^{1}$ \\ Robson Bonomo ${ }^{2}$ \\ Fábio Ribeiro Pires ${ }^{3}$}

Resumo: Objetivou-se a partir de uma equação ajustada, estimar a erosividade da chuva para os dois anos de setembro de 2014 a agosto de 2015 e setembro de 2015 a agosto de 2016 para o município de São Mateus-ES. Os dados de precipitação foram obtidos na Estação Meteorológica Automática localizada no Centro Universitário Norte do Espírito Santo-Ceunes. A erosividade da chuva foi estimada a partir da equação $E C_{30}=6,4492^{*}$ pi $-391,63$, em que $E C_{30}=$ produto da energia cinética da chuva pela sua intensidade máxima em $30 \mathrm{~mm}$ (MJ ha-1 $\mathrm{mm} \mathrm{h}^{-1}$ ano $^{-1}$ ) e pi = precipitação média anual (mm).A precipitação total foi de 765,4 mm e 272,4 para os períodos de 2014/2015 e 2015/2016, respectivamente. Com precipitações médias de $63,8 \mathrm{~mm}\left(1^{\circ}\right.$ ano) e 22,7 mm ( $2^{\circ}$ ano). O mês de outubro de 2014 apresentou a maior precipitação mensal, 183,6 mm. A energia cinética foi de 4544,59 $\mathrm{MJ} \mathrm{ha}^{-1} \mathrm{~mm} \mathrm{~h}^{-1}$ ano-1 para o $1^{\circ}$ ano (2014/2015) e de 1.365,13 $\mathrm{MJ} \mathrm{ha}^{-1} \mathrm{~mm} \mathrm{~h}^{-1}$ ano ${ }^{-1}$ para o $2^{\circ}$ ano (2015/2016). A erosividade da chuva para o período foi de 5.909,72 $\mathrm{MJ} \mathrm{ha}^{-1} \mathrm{~mm} \mathrm{~h}^{-1}$ ano-1. O primeiro ano (2014/2015) apresentou a maior precitipação total. A erosividade da chuva para o período foi de $5.909,72 \mathrm{MJ} \mathrm{ha}^{-1} \mathrm{~mm} \mathrm{~h}^{-1} \mathrm{ano}^{-1}$, sendo considerada como média-forte.

Palavras-chave: Estação Meteorológica; Precipitação mensal; Energia cinética.

\footnotetext{
${ }^{1}$ Curso/Instituição, País. E-mail: Agronomia/Ceunes - UFES, Brasil. E-mail: cardoso.dione@gmail.

2 Curso/Instituição, País. E-mail: Agronomia/Ceunes - UFES, Brasil. E-mail: robson.bonomo@gmail.com.

${ }^{3}$ Curso/Instituição, País. E-mail: Agronomia/Ceunes - UFES, Brasil. E-mail: pires.fr@gmail.com.
} 